\title{
Correction: Reduced Crowding and Poor Contour Detection in Schizophrenia Are Consistent with Weak Surround Inhibition
}

\section{Valentina Robol, Marc S. Tibber, Elaine J. Anderson, Tracy Bobin, Patricia Carlin,} Sukhwinder S. Shergill, Steven C. Dakin

The following information is missing from the Funding statement: This study was supported by the European Research Council Executive Agency (ERC).

\section{Reference}

1. Robol V, Tibber MS, Anderson EJ, Bobin T, Carlin P, Shergill SS, et al. (2013) Reduced Crowding and Poor Contour Detection in Schizophrenia Are Consistent with Weak Surround Inhibition. PLoS ONE 8 (4): e60951. https://doi.org/10.1371/journal.pone.0060951 PMID: 23585865

G open ACCESS

Citation: Robol V, Tibber MS, Anderson EJ, Bobin T, Carlin P, Shergill SS, et al. (2019) Correction: Reduced Crowding and Poor Contour Detection in Schizophrenia Are Consistent with Weak Surround Inhibition. PLoS ONE 14(6): e0218483. https://doi. org/10.1371/journal.pone.0218483

Published: June 13, 2019

Copyright: @ 2019 Robol et al. This is an open access article distributed under the terms of the Creative Commons Attribution License, which permits unrestricted use, distribution, and reproduction in any medium, provided the original author and source are credited. 